\title{
Systematic Literature Review and Bibliometric Study of Waste Management in Indonesia in the COVID-19 Pandemic Era
}

\author{
Dave Mangindaan ${ }^{1, *(\mathbb{D}}$, Azmier Adib ${ }^{2}$, Harvey Febrianta ${ }^{3}$ and Donald John Calvien Hutabarat ${ }^{3}$ \\ 1 Profesional Engineer Program Department, Faculty of Engineering, Bina Nusantara University, \\ Jakarta 11480, Indonesia \\ 2 Independent Researcher, West Jakarta 11510, Indonesia; azmier.adib@gmail.com \\ 3 Food Technology Department, Faculty of Engineering, Bina Nusantara University, Jakarta 11480, Indonesia; \\ harvey.febrianta@binus.ac.id (H.F.); donald.calvien@binus.ac.id (D.J.C.H.) \\ * Correspondence: dave.mangindaan@binus.ac.id
}

\section{check for} updates

Citation: Mangindaan, D.; Adib, A.; Febrianta, H.; Hutabarat, D.J.C. Systematic Literature Review and Bibliometric Study of Waste Management in Indonesia in the COVID-19 Pandemic Era.

Sustainability 2022, 14, 2556.

https://doi.org/10.3390/

su14052556

Academic Editors: Mengge Dong and Silvia Fiore

Received: 11 January 2022

Accepted: 21 February 2022

Published: 23 February 2022

Publisher's Note: MDPI stays neutral with regard to jurisdictional claims in published maps and institutional affiliations.

Copyright: (C) 2022 by the authors. Licensee MDPI, Basel, Switzerland. This article is an open access article distributed under the terms and conditions of the Creative Commons Attribution (CC BY) license (https:// creativecommons.org/licenses/by/ $4.0 /)$.

\begin{abstract}
It is globally known that the COVID-19 pandemic affected all aspects of society, including issues pertaining to health, economic, social, and environmental issues. The pandemic has already continued for two years and counting, and we are now advised to live coexisting with COVID19 in the new normal era. During this new normal era, especially in Indonesia, many medical wastes (face masks, gloves, goggles, etc.) and other type of wastes are being generated due to COVID-19. However, the waste profile (waste management or waste handling) and the specific waste distribution in Indonesia during COVID-19 is not clearly understood. Therefore, in this study we perform a systematic literature review and bibliometric analysis of studies published during COVID-19 to describe the aforementioned issues regarding waste management in Indonesia by extracting data from Scopus as a leading indexing service for peer-reviewed publications. From more than 230,000 titles in Scopus regarding COVID-19, there are only 24 titles related to waste management in Indonesia during COVID-19. From the bibliometric analysis of the extracted data from Scopus, it can be observed that there are four clusters of interest, namely (1) medical waste and its processing, (2) COVID-19-related issues, (3) Indonesia and waste management, and (4) solid waste. The study of these issues is essential to obtain not only a clean environment, but also a sustainable future for an Indonesia that is free from COVID-19 and other related diseases in the future. Moreover, the bibliometric analysis also uncovers the research and publication gap for the topic of waste management in Indonesia in the COVID-19 pandemic era.
\end{abstract}

Keywords: COVID-19; waste management; bibliometric; Scopus; environment; medical waste

\section{Introduction}

COVID-19 has struck as a global pandemic, and Indonesia is one of the affected countries, with a total of around 4.2 million cases, which ranks as the 14th most affected county in the world. [1]. However, on the bright side, by being the 4th largest population in the world with 277 million peoples, the total cases per one million Indonesian populations are only 15,148 , less than half that of the global indicator of 36,801 cases per one million populations [1]. This optimistic fact is fueling Indonesia along the road to its recovery, not just in the arena of health care, but also in the fields of economy and environment.

On the other hand, from the environmental point of view, the COVID-19 cases in Indonesia bring a significant change in terms of waste generation and waste management. It is reported that in the early days of outbreak, COVID-19 serendipitously reduced air pollution and emissions [2]. However, after around two years of the pandemic, there are extraordinary increases in medical wastes (face masks and personal protection equipment (PPE), gloves, goggles) not just in hospitals [3], but also in bodies of water [4]. This huge spike in waste has overwhelmed hospitals [3] and waste banks [5]. Conventional treatments cannot treat the medical wastes optimally [6,7], and along with physical and 
social limitations due to COVID-19 health protocols, the public and the academic population cannot entirely perform waste management community service [8].

In order to comprehend the profile of waste handling and waste management in Indonesia during the COVID-19 pandemic era, this paper of systematic literature review and bibliometric analysis aims to identify and illustrate the current situation of waste generation in Indonesia through the perspective of Scopus-indexed publications. Furthermore, it is also prepared to reveal the research and publication gap for the topic of waste handling or management in Indonesia during the COVID-19 pandemic. To the best of our knowledge, this type of analysis or review has not been conducted for the scope of Indonesia during COVID-19, although there are reports on this topic for other Asian countries, such as clinical waste in Malaysia [9], COVID-19-associated waste management in India [10], and biomedical waste in Bangladesh [11].

This paper is organized as follows: Section 1 describes the motivation and background of this study related to COVID-19 and waste in Indonesia, reviewed from the perspective of the literature in the Scopus database. The bibliometric data from Scopus in the aforementioned topic are extracted using procedures detailed in Section 2. The extracted data are analyzed and the results are discussed in Section 3, with two subsections, namely (a) systematic literature review, and (b) bibliometric analysis. Based on the findings in this paper, future recommendations are listed in Section 4, and finally Section 5 presents the conclusions.

\section{Materials and Methods}

The systematic literature review and bibliometric analysis in this study were performed by accessing the Scopus database (https:/ / scopus.com (accessed on 3 December 2021)). Scopus was chosen because it is one of the largest databases of abstracts and citations, journals, conference papers, and books. More importantly, the Scopus Content Selection and Advisory Board thoroughly audits the contents indexed by Scopus [12]. The following keywords were inputted into the Scopus web search: "COVID", "Indonesia", and "waste", with the affiliation country is limited to Indonesia. This query can be written as (TITLEABS-KEY (covid)) AND ((indonesia)) AND (waste) AND (LIMIT-TO (AFFILCOUNTRY, "Indonesia")) in the form of Boolean search.

The detailed systematic literature search (Preferred Reporting Items for Systematic Reviews and Meta-Analyses, PRISMA) from the Scopus database is shown in Figure 1. First, when the keyword "covid" was inputted, more than 230,000 titles were shown. The entry was further limited using the keyword "Indonesia", and the affiliation country "Indonesia", where the results were reduced down to 6704 and 3637 titles, respectively. Finally, for data extraction from Scopus, the keyword "waste" was applied, resulting in 133 titles (including abstract, author keywords, index keywords, affiliation, and other bibliographical information). From the 133 titles, further abstract selection was employed to sort them down to 36 papers. Furthermore, the focus of the selection was narrowed by the removal of papers with minimum adherence to the topic of waste management in Indonesia in the COVID-19 pandemic era, yielding 24 key papers to be discussed in detail in this report.

Besides the systematic literature review procedure mentioned previously, this study also applied bibliometric analysis, where the 24 key papers (along with their bibliographic information) were analyzed by using VOSviewer software. From the VOSviewer analysis, a visualization of the web of connected keywords from the 24 key papers was obtained. The interlinked information demonstrated the profile of the Scopus publications on waste management in Indonesia in the COVID-19 pandemic era, and also identified the research or publication gap about waste management in Indonesia during the COVID-19 pandemic. 


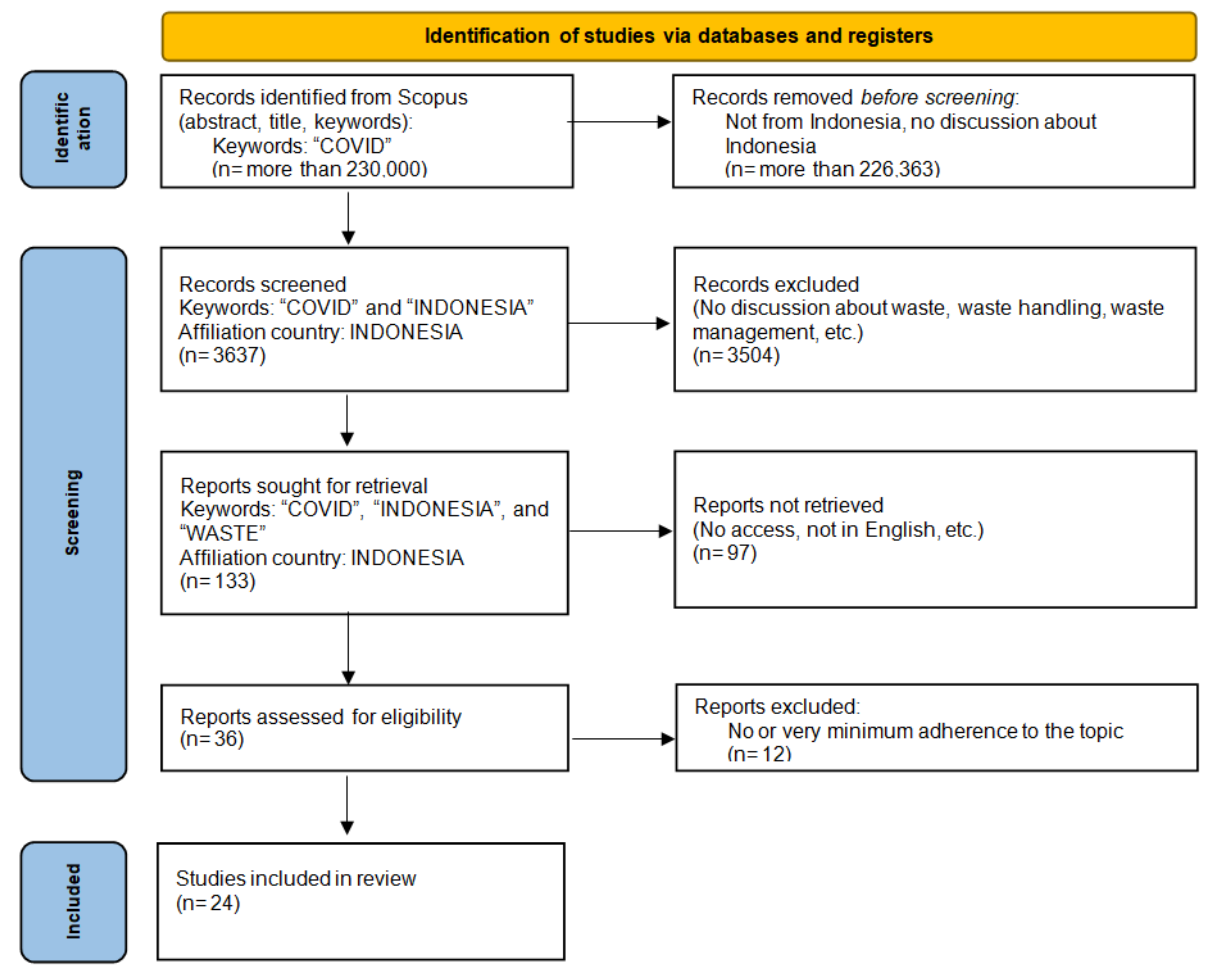

Figure 1. The Preferred Reporting Items for Systematic Reviews and Meta-Analyses (PRISMA) for this study.

\section{Results}

\subsection{Systematic Literature Review}

The 24 key papers resulting from the systematic literature review using the Scopus database for the topic of waste management in Indonesia in the COVID-19 pandemic are shown in Table 1. It can be observed that there are various types of waste handling or waste management, namely (1) destruction, (2) preventive design, (3) alternative use of waste, and (4) analysis or survey. For the conventional method of destruction, the type of waste ranges from biomass waste (coconut shell) [13] to, most dominantly in the COVID-19 era, a variety of medical wastes such as personal protective equipment, masks, gloves, diapers, etc.) [6,14-16]. The destruction of the coconut biomass is improved using postharvest technology sourcing the IoT (internet of things system), while the destruction of medical wastes commonly uses thermochemical processes such as pyrolysis, incineration, torrefaction, and gasification. In particular, one study [16] proposed incineration as the technology of choice and performed the analysis and calculation for the theoretical energy yield of the incinerated waste.

Besides the conventional destruction processes, there are also reports suggesting a preventive design to avoid or minimize the generation of waste, as well as studies about creative ways to use waste for other economical products. In a study, when designing a non-medical mask, the AHP (analytic hierarchy process) is employed for determining the appropriate material (quilting cotton, $600 \mathrm{TPI}$ ) for increasing the environmental friendliness of the product [17]. On the other hand, an innovation of an ergonomic and smart trash bin is also studied [18]. More importantly, the preventive design was also utilized for creation of several smart city models [19] in locations such as Jakarta, Banyuwangi, Makassar, Semarang, and Surabaya. The plans for the construction of the smart city models include the design for waste banks, waste pickup services, smart apps, recycling plans, etc. In the creative industry, plastic and electronic cable waste (e-waste) are converted into beautiful dividers for cafés and restaurants [20], or in the agricultural sector, organic waste such as tofu and tempeh waste are mixed with algae as goat feed [21] to aid in the production of goat milk for maintaining of health during COVID-19. 
Because of the limitation of movement and transportation during COVID-19, there most publications dealt solely with the analysis of waste management in Indonesia during the pandemic. Although no physical treatment of the waste was reported, the key analytical papers are nevertheless considered important for the development of future waste management and/or recommendations to government policy makers for the development of policies related to waste, health, or environment in Indonesia. A survey [22] of face mask users ( $n=266$ respondents) reveals that $79.3 \%$ wear reusable masks and $19.5 \%$ of them do not wash the reusable material; some still dispose of the masks mixed with domestic waste. In another survey [23] concerning visitors to food and beverage sites during COVID-19 ( $n=500$ respondents), 52\% of the respondents said that they never visited a bar, restaurant, or hotel during COVID-19. Therefore, this situation might generate uncertainty in the F\&B industry, hence more food waste and an increase in stale foods. Increasing food waste must be curbed or prevented by the involvement of the government in applying new policies to support not only health, but also the economy and the environment. Besides the aforementioned surveys, other publications related to the analysis of waste management in Indonesia during the COVID-19 pandemic era deals with the socioeconomic analysis of the closed-loop waste bank in Surabaya, East Java province, Indonesia [5], where about 50\% of the waste bank has become inactive due to COVID-19; therefore, more government action and policies must be employed to support the Indonesian economy and environment.

There are also analyses of waste handling and waste management in Indonesia related to medical waste, mostly medical masks. It is found that before pandemic, there were 366 tons of medical wastes collected daily from 2813 hospitals. The COVID-19 era brought a surge of five times the previous amount of medical waste. In addition, the condition is exacerbated due to the fact that only 82 hospitals have a licensed incinerator available on their premise (out of 2899 hospitals) [3]. Of all the other alternatives (kilns, furnaces, burial, etc.) [24], the incinerator is considered as an important thermal destructive treatment to degrade medical and PPE waste due to its ability to degrade the microorganisms and pathogens in these medical wastes. A microbiome analysis of waste masks shows that there are $47 \%$ coliform and $20 \%$ pathogen microorganisms in waste masks [25]. In order to enable rapid microbial screening of waste mask treatment, a gene marker, called the ORF1, gene was reported [26].

Besides the emergence of increased waste in hospitals, it was also recently reported that the majority of the river debris in Jakarta Bay is plastic, with an abundance of $46 \%$ (or a weight of $57 \%$ of total river waste mass), with a significant increase in the amount (around 15\%) of PPE (medical masks, gloves, hazard suits, face shields, raincoats) in river debris, with average abundance of 780 items, or $130 \mathrm{~kg}$ per day [4]. Moreover, COVID-19 waste also advises an analysis of the challenges of handling hazardous medical waste using information technology (including regulation, technology, financial, and awareness) [27]. Related to the aforementioned river pollution, sewage and wastewater [28,29] are also contaminated with COVID-19, especially from stools in the sewage [30], therefore initiating a proposal for the institutionalization of wastewater surveillance systems to monitor COVID-19 in wastewater [31].

Last but not least, air pollution or emission was also an important area of study, with a report that the use of life cycle assessment (LCA) [32] revealed a decrease in COVID-19 related wastes, with reported reductions in and methane and carbon dioxide emissions, as well as DOC (dissolved organic carbon, or solid waste). In addition, in early 2020 when COVID-19 was only a few months old, there are several publications related to solid, air, and water pollution, such as an analysis using SNI 19-3964-1994 showing reduction of solid waste and air emissions during COVID-19 [2], and also a review of coronavirus temperature dependence and survival in sewage water with recommendations for plumbing systems for COVID-19 [33]. However, as the virus evolves and global society prepares for the new normal, the aforementioned publications from the early days of COVID-19 are not considered to fully reflect the current conditions as the virus evolves and global society prepares protocols for a new normal. 
Table 1. Selected key papers reporting various types of waste and their handling(s) or management in Indonesia in the COVID-19 pandemic era, as indexed using the Scopus database.

\begin{tabular}{|c|c|c|c|c|}
\hline No. & Type(s) of Waste Handling & Type of Waste & Results & Ref. \\
\hline 1. & Destruction & $\begin{array}{l}\text { Coconut shell biomass waste with variations } \\
\text { in the number of shells: } 6,8,10 \text {, and } 14\end{array}$ & $\begin{array}{l}\text { Creation of biomass-based post-harvest } \\
\text { technology innovations using the internet of } \\
\text { things system }\end{array}$ & [13] \\
\hline 2. & Destruction & $\begin{array}{l}\text { Medical waste of personal } \\
\text { protective equipment }\end{array}$ & $\begin{array}{l}\text { Destruction of waste, preferably by } \\
\text { using pyrolysis }\end{array}$ & [6] \\
\hline 3. & Destruction & $\begin{array}{l}\text { Plastic medical wastes (polyethylene, } \\
\text { polypropylene, polystyrene, polyethylene } \\
\text { terephthalate, and nylon) }\end{array}$ & $\begin{array}{l}\text { Pyrolysis of waste (to produce energy } \\
\text { products like oil, gas, and char) }\end{array}$ & [14] \\
\hline 4. & $\begin{array}{ll}- & \text { Destruction } \\
\text { - } & \text { Analysis }\end{array}$ & $\begin{array}{l}\text { Medical wastes (about } 54,000 \text { ton/day as of } \\
22 \text { November } 2020 \text { ), including face masks, } \\
\text { gloves, clothes, goggles, and } \\
\text { sanitizer/disinfectant }\end{array}$ & $\begin{array}{l}\text { Thermochemical processes for waste } \\
\text { processing, including incineration, } \\
\text { torrefaction, pyrolysis, and gasification }\end{array}$ & [15] \\
\hline 5. & $\begin{array}{ll}- & \text { Destruction } \\
- & \text { Analysis } \\
\end{array}$ & Marine debris, diapers, organic wastes & $\begin{array}{l}\text { Incineration (theoretical calculation of energy } \\
\text { yield from incinerated waste) }\end{array}$ & [16] \\
\hline 6. & Preventive design & Mask & $\begin{array}{l}\text { Usage of AHP (analytic hierarchy process) } \\
\text { for determining the appropriate material } \\
\text { (quilting cotton, } 600 \text { TPI) for environmentally } \\
\text { friendly non-medical mask }\end{array}$ & [17] \\
\hline 7. & Preventive design & Medical waste & $\begin{array}{l}\text { Preventive design of ergonomic and smart } \\
\text { trash bin }\end{array}$ & [18] \\
\hline 8. & $\begin{array}{l}\text { - } \quad \text { Preventive design } \\
\text { Analysis }\end{array}$ & $\begin{array}{l}\text { Smart environment concept for smart cities } \\
\rightarrow \text { technological and social innovation } \\
\text { approaches to improve medical and domestic } \\
\text { waste management, public service systems, } \\
\text { and the socialization of environmental } \\
\text { protection programs }\end{array}$ & $\begin{array}{l}\text { DKI Jakarta province: } \\
\text { - } \quad \text { Pick-up service for infectious waste } \\
\text { - } \quad \text { DAKI Smart City platform } \\
\text { Development plan for the intermediate } \\
\text { Banyuwangi management facilities } \\
\text { - } \quad \text { Pick-up service of domestic waste } \\
\text { - } \quad \text { Oniat Mobile Garbage Bank apps } \\
\text { Online service of environmental quality } \\
\text { Makassar city: } \\
\text { - } \quad \text { Waste bank } \\
\text { - } \quad \text { Gducation of waste separation } \\
\text { garbage mall (collaboration between } \\
\text { Semarnment and private sector in waste } \\
\text { management) } \\
\text { - } \quad \text { Drop box and safety box for medical } \\
\text { waste } \\
\text { CCTV for environmental monitoring } \\
\text { Disinfection via eco-enzyme spraying } \\
\text { - } \quad \text { Zeta Green air purifier } \\
\text { Surabaya city: } \\
\text { - } \quad \text { Infectious waste separation in } \\
\text { temporary garbage dump } \\
\text { Recycling waste mask (collaboration } \\
\text { with Institut Teknologi Sepuluh } \\
\text { Nopember) }\end{array}$ & [19] \\
\hline 9. & Alternative use of waste & $\begin{array}{l}\text { Plastic waste and Electronic cable waste } \\
\text { (e-waste) }\end{array}$ & $\begin{array}{l}\text { Recycling of e-waste (plastic and cable) as a } \\
\text { divider for cafes }\end{array}$ & [20] \\
\hline 10. & Alternative use of waste & $\begin{array}{l}\text { Tofu waste and tempeh waste, combined } \\
\text { with microalgae Chlorella vulgaris }\end{array}$ & $\begin{array}{l}\text { Alternative use of organic waste as a feed for } \\
\text { goats to produce goat milk for COVID- } 19\end{array}$ & [21] \\
\hline
\end{tabular}


Table 1. Cont.

\begin{tabular}{|c|c|c|c|c|}
\hline No. & Type(s) of Waste Handling & Type of Waste & Results & Ref. \\
\hline 11. & $\begin{array}{ll}- & \text { Analysis } \\
- & \text { Survey }\end{array}$ & Face mask & $\begin{array}{l}\text { Profile of face mask user, with } \\
266 \text { respondents, } 79.3 \% \text { wear reusable masks, } \\
24.8 \% \text { choose wrong/inappropriate material, } \\
19.5 \% \text { do not wash the reusable material, and } \\
\text { some still dispose the masks mixed with } \\
\text { domestic waste. }\end{array}$ & [22] \\
\hline 12. & Analysis & General waste & $\begin{array}{l}\text { Socioeconomic analysis of the waste bank } \\
\text { closed-loop system in Surabaya City. }\end{array}$ & [5] \\
\hline 13. & $\begin{array}{ll}\text { - } & \text { Analysis } \\
\text { Survey }\end{array}$ & $\begin{array}{l}\text { Food waste and stale food in restaurants, } \\
\text { bars, and hotels }\end{array}$ & $\begin{array}{l}\text { Profile of visitors to food and beverage } \\
\text { locations during COVID-19 ( } 500 \text { respondents, } \\
52 \% \text { never visit bars, restaurants, hotels, } \\
\text { where this condition might generate } \\
\text { uncertainty in the F\&B industry, hence more } \\
\text { food waste and stale foods) }\end{array}$ & [23] \\
\hline 14. & Analysis & Medical waste & $\begin{array}{l}\text { Before pandemic: } 366 \text { tons per day of } \\
\text { medical waste from } 2813 \text { hospitals } \\
\text { - } \quad \text { After pandemic: Surge of five times. } \\
\text { Only } 82 \text { hospitals possess licensed } \\
\text { incinerators (from total of 2899) }\end{array}$ & [3] \\
\hline 15. & Analysis & Medical mask & $\begin{array}{l}\text { Microbiome analysis of mask waste-there } \\
\text { are } 47 \% \text { coliform, } 20 \% \text { pathogen microbes, } \\
\text { and } 33 \% \text { uncharacterized microbes }\end{array}$ & [25] \\
\hline 16. & Analysis & Medical mask & $\begin{array}{l}\text { ORF1 gene as a gene marker for rapid } \\
\text { screening of mask waste treatment }\end{array}$ & [26] \\
\hline 17. & Analysis & $\begin{array}{l}\text { Used personal protective equipment (PPE, } \\
\text { facemasks, gloves, and other protective } \\
\text { items) }\end{array}$ & $\begin{array}{l}\text { Analysis of possibilities for treating used } \\
\text { PPE: co-disposal in a municipal solid waste } \\
\text { incinerator, cement kilns, industrial furnaces, } \\
\text { and deep burial }\end{array}$ & [24] \\
\hline 18. & Analysis & $\begin{array}{l}\text { PPE (medical masks, gloves, hazard suits, } \\
\text { face shields, raincoats) }\end{array}$ & $\begin{array}{l}\text { Majority of the river debris is plastic, } \\
\text { with abundance of } 46 \% \text {, or weight of } \\
57 \% \text { of total river waste mass. } \\
\text { Spike in the amount of PPE (medical } \\
\text { masks, gloves, hazard suits, face } \\
\text { shields, raincoats), around } 15 \% \text { of river } \\
\text { debris, with average abundance of } \\
780 \text { items, or } 130 \mathrm{~kg} \text { per day. }\end{array}$ & [4] \\
\hline 19. & Analysis & Hazardous medical waste & $\begin{array}{l}\text { Analysis of the challenges of handling } \\
\text { hazardous medical waste using information } \\
\text { technology (including regulation, technology, } \\
\text { financial, and awareness) }\end{array}$ & [27] \\
\hline 20. & Analysis & Sewage and wastewater & $\begin{array}{l}\text { Analysis of COVID-19 virus in stools } \\
\text { from sewage }\end{array}$ & [30] \\
\hline 21. & Analysis & Wastewater & $\begin{array}{l}\text { Proposed institutionalization of wastewater } \\
\text { surveillance systems to monitor COVID-19 } \\
\text { in wastewater }\end{array}$ & [31] \\
\hline 22. & Analysis & $\begin{array}{ll}\text { - } & \text { Solid waste } \\
& \text { Air emission }\end{array}$ & $\begin{array}{l}\text { Life cycle assessment (LCA) analysis to } \\
\text { reveal the decrease in wastes. There are } \\
\text { reductions of DOC (dissolved organic } \\
\text { carbon) and methane and } \mathrm{CO}_{2} \text { emission. }\end{array}$ & [32] \\
\hline 23. & Analysis & $\begin{array}{ll}- & \text { Solid waste } \\
\text { - } & \text { Air emissions }\end{array}$ & $\begin{array}{l}\text { Analysis using SNI 19-3964-1994 shows } \\
\text { reduction of solid waste and air emissions } \\
\text { during COVID-19 }\end{array}$ & [2] \\
\hline 24. & Analysis & Sewage and wastewater & $\begin{array}{l}\text { Review of coronavirus temperature } \\
\text { dependence and survival in sewage water } \\
\text { and recommendations for plumbing system } \\
\text { for COVID-19 }\end{array}$ & [33] \\
\hline
\end{tabular}


The distribution of the types of waste handling or waste management noted in this study is shown in Figure 2. It is shown that out of 24 key publications discussed in this paper, analysis-based papers dominate with $58 \%$ of the total, followed by those dealing with conventional degradation processes $(21 \%)$, creative preventive design $(13 \%)$, and the innovative use of waste $(8 \%)$. This finding provides preliminary analysis for further development of waste management in Indonesia, especially after the COVID-19 pandemic is over, where further exploration of the preventive design and alternative use of waste is suggested, especially for the development of a better sustainable environment in Indonesia.

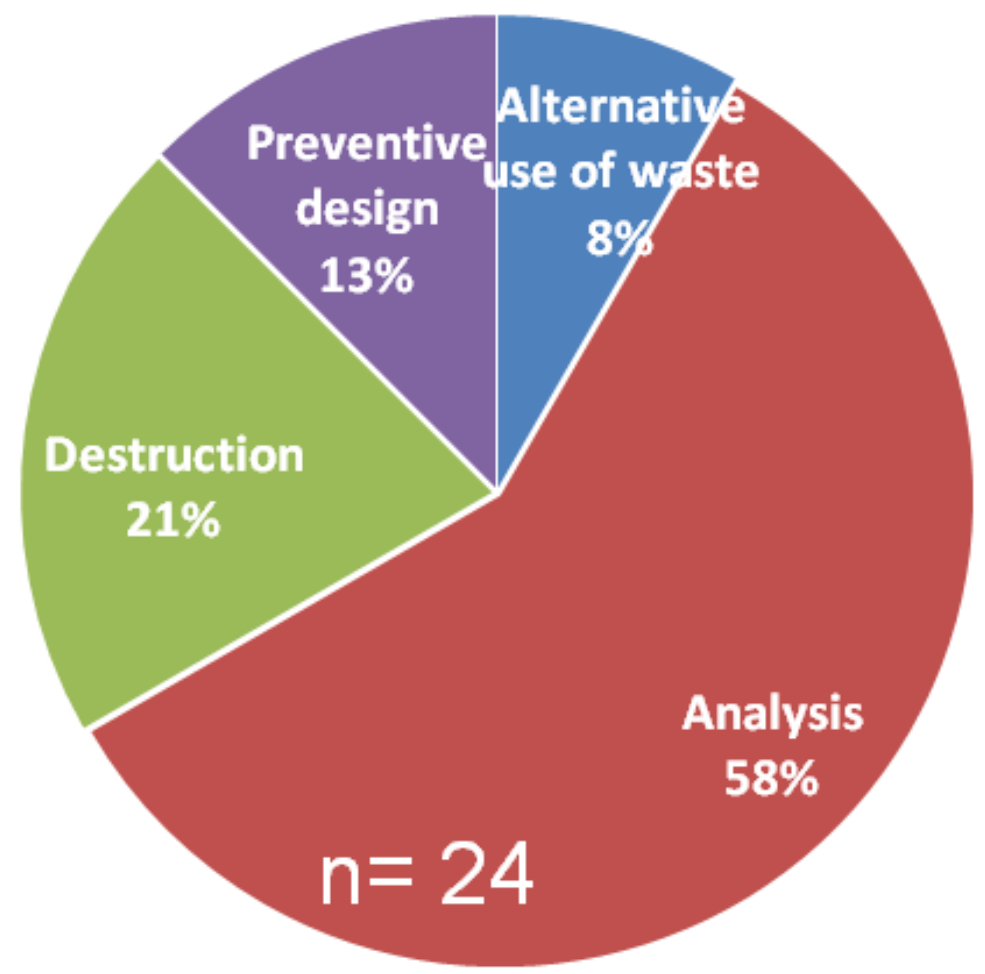

Figure 2. The distribution of the type of waste handling or management covered in this study.

\subsection{Bibiliometric Analysis}

To reinforce the findings from our systematic literature review, a bibliometric analysis is also carried out. For the 24 key papers on the topic of waste management in Indonesia in the COVID-19 pandemic era, the keywords are visualized in Figure 3 as an output from VOSviewer software. Four distinct clusters are identified, namely:

1 Wastes and their treatments (red)

2 COVID-19 (green)

3 Indonesia and waste management (blue)

4 Solid waste (yellow) Table 2.

Moreover, the detailed content of each cluster and its strength (weight) are shown in 


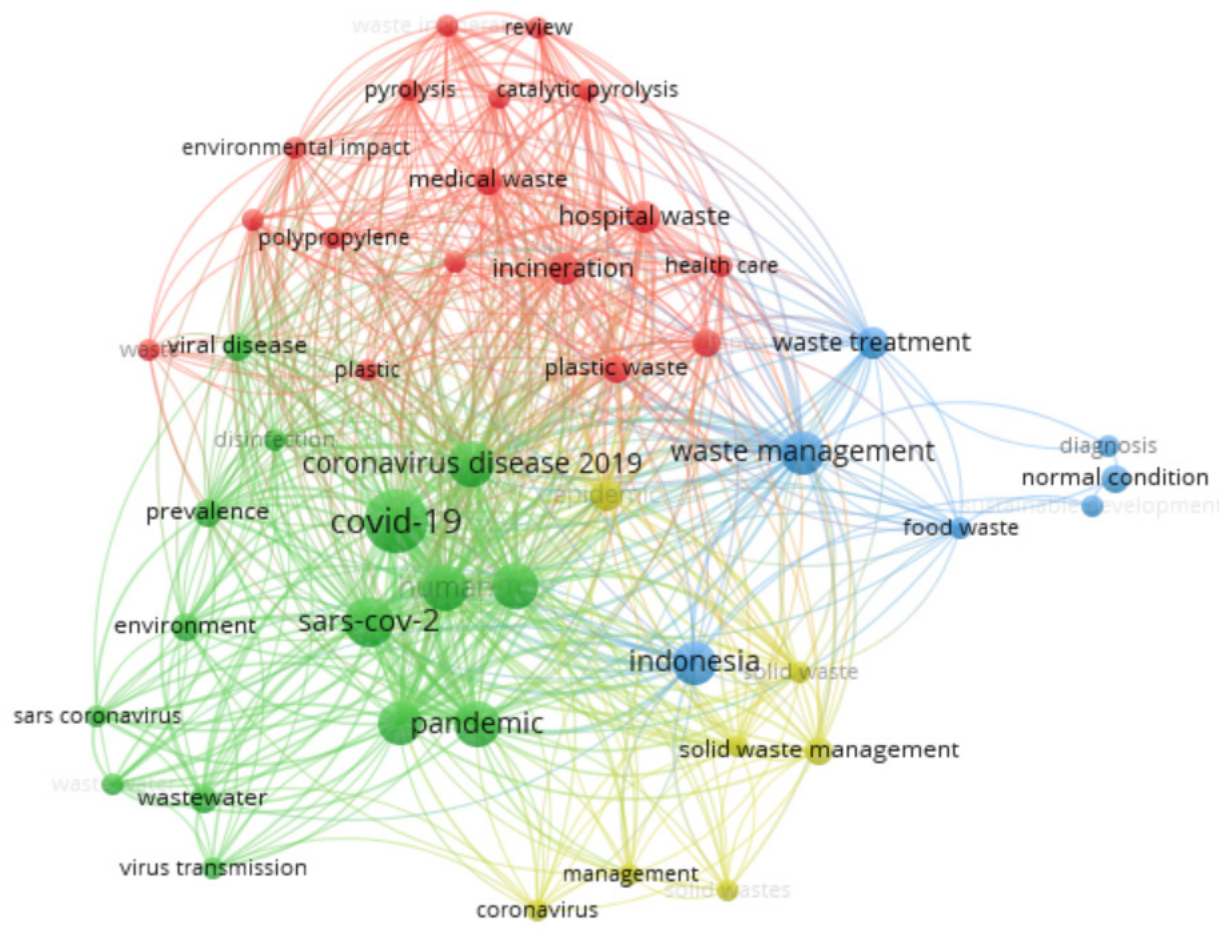

Figure 3. The bibliometric analysis of waste management in Indonesia during the COVID-19 pandemic era.

Table 2. Important keywords from 24 Scopus-indexed key papers in this study, as obtained by bibliometric analysis using VOSviewer software.

\begin{tabular}{cccc}
\hline No. & Label & Cluster & Weight \\
\hline 1. & hospital waste & 1 & 33 \\
\hline 2. & incineration & 1 & 33 \\
\hline 3. & plastic waste & 1 & 31 \\
\hline 4. & health care & 1 & 29 \\
\hline 5. & medical waste & 1 & 29 \\
\hline 6. & waste disposal & 1 & 29 \\
\hline 7. & polypropylene & 1 & 28 \\
\hline 8. & polypropylenes & 1 & 28 \\
\hline 9. & medical waste management & 1 & 26 \\
\hline 10. & catalytic pyrolysis & 1 & 25 \\
\hline 11. & energy conversion & 1 & 25 \\
\hline 12. & pyrolysis & 1 & 25 \\
\hline 13. & review & 1 & 25 \\
\hline 14. & waste incineration & 1 & 23 \\
\hline 15. & environmental impact & 1 & 15 \\
\hline 16. & plastic & 1 & 15 \\
\hline 17. & waste & 1 & 42 \\
\hline 18. & coronavirus disease 2019 & 2 & 42 \\
\hline 19. & human & 2 & \\
\hline 20. & & 2 & 19 \\
\hline
\end{tabular}


Table 2. Cont.

\begin{tabular}{|c|c|c|c|}
\hline No. & Label & Cluster & Weight \\
\hline 21. & humans & 2 & 42 \\
\hline 22. & SARS-CoV-2 & 2 & 42 \\
\hline 23. & pandemic & 2 & 37 \\
\hline 24. & pandemics & 2 & 37 \\
\hline 25. & prevalence & 2 & 31 \\
\hline 26. & disinfection & 2 & 29 \\
\hline 27. & viral disease & 2 & 28 \\
\hline 28. & environment & 2 & 21 \\
\hline 29. & wastewater & 2 & 16 \\
\hline 30. & sars coronavirus & 2 & 15 \\
\hline 31. & waste water & 2 & 15 \\
\hline 32. & virus transmission & 2 & 14 \\
\hline 33. & waste management & 3 & 38 \\
\hline 34. & indonesia & 3 & 28 \\
\hline 35. & waste treatment & 3 & 27 \\
\hline 36. & food waste & 3 & 20 \\
\hline 37. & diagnosis & 3 & 3 \\
\hline 38. & normal condition & 3 & 3 \\
\hline 39. & sustainable development & 3 & 3 \\
\hline 40. & epidemic & 4 & 37 \\
\hline 41. & government & 4 & 22 \\
\hline 42. & solid waste & 4 & 22 \\
\hline 43. & solid waste management & 4 & 22 \\
\hline 44. & coronavirus & 4 & 17 \\
\hline 45. & management & 4 & 16 \\
\hline 46. & solid wastes & 4 & 15 \\
\hline
\end{tabular}

From Table 2 and Figure 3, it can be seen that the red and green clusters are more dominant than the blue and yellow ones. The red (related to waste and its treatments) and green (related to COVID-19) clusters are comparable in the number of important keywords (17, and 15 keywords, respectively), and for their weight or frequency (444, and 453 , respectively). This finding is due to the nature of waste treatment and COVID-19 as global issues related to society and the environment. On the other hand, the blue (related to Indonesia and waste management) and yellow (related to solid waste) clusters are more specialized and result from narrower scopes of the red and green clusters. Certainly, the blue and yellow clusters are less dominant than that of the red and green ones, with fewer keywords (only seven keywords each) and lighter weight (122 and 151), respectively. Nevertheless, they occupy an important place in completing the whole picture of waste management in Indonesia during COVID-19 pandemic era.

In addition to visualizing the keywords for the research of waste management in Indonesia in the COVID-19 pandemic era, as shown in Figure 3, and with the detailed content of the interlinked web of keywords tabulated in Table 2, the bibliometric analysis also provides highly useful insights, as depicted in Figure 4 . This figure is similar to Figure 3, but with the focus on the keyword "indonesia". When this particular keyword is hovered over using the VOSviewer software, all the connections to it are revealed, as well as the keywords with no connection to "indonesia". It is shown that there are several keywords not correlated with "indonesia", namely "review", "pyrolysis", "catalytic pyrolysis", "environmental impact", "medical waste management", and "health care". 
These keywords, therefore, can be assumed as the research and publication gap for the topic of waste management in Indonesia in the COVID-19 pandemic era. Therefore, as the keyword "review" is one of the research and publication gaps, this paper as a systematic literature review and bibliometric analysis serves to close that particular gap by functioning as a pioneering exploration for further research related to waste management in Indonesia in the COVID-19 or post-COVID-19 era.

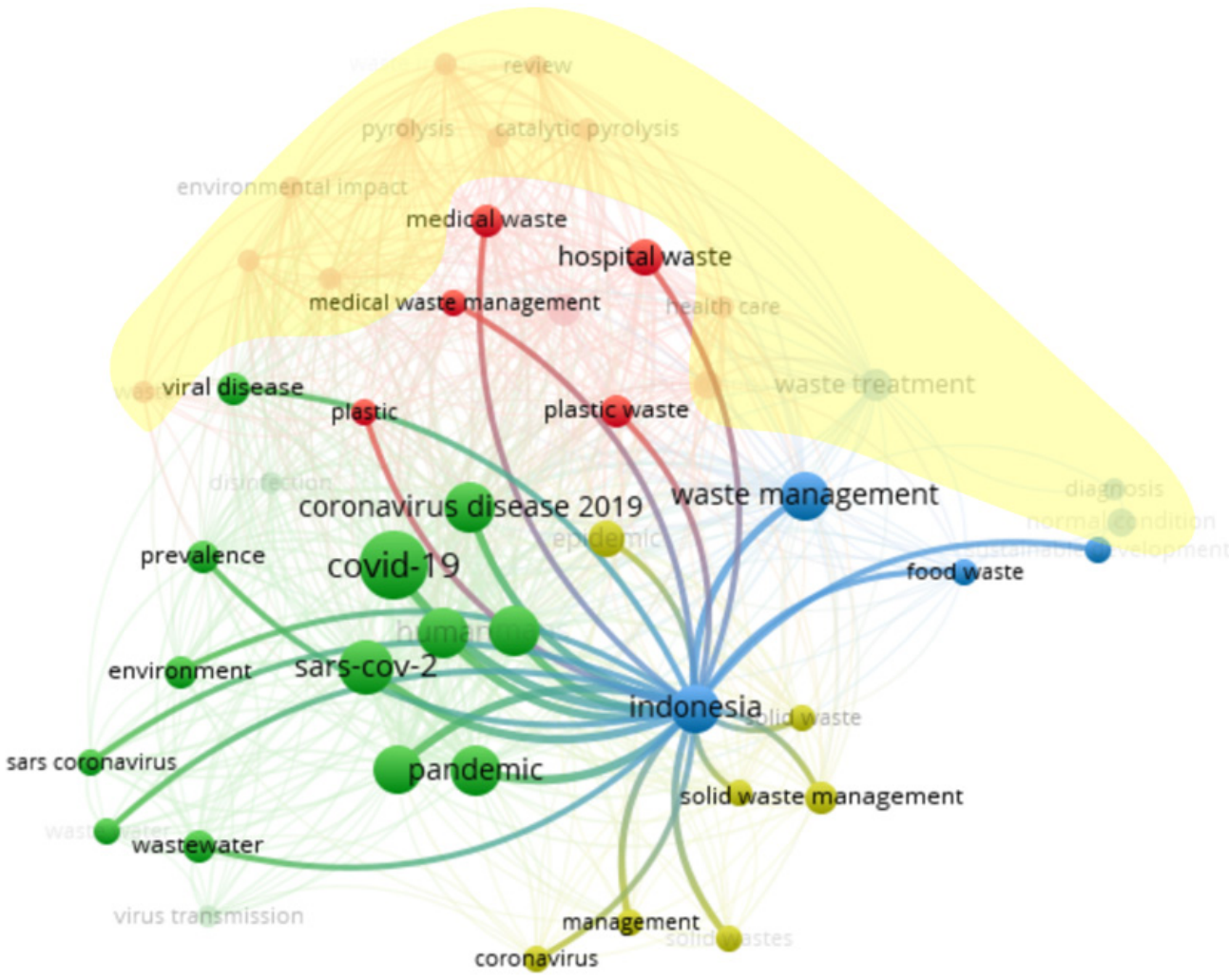

Figure 4. The research and publication gap related to waste management in Indonesia in the COVID-19 pandemic era.

\section{Future Recommendations}

Based on the results and findings in the previous section, there are some points to be highlighted as future recommendations. From the point of view of sustainability, it is urged that after the COVID-19 pandemic is over, in regard to waste handling via destruction, we must explore additional waste handling processes in order to achieve a sustainable environment. Those processes include:

a Preventive design - this handling process is focusing on preventing and or minimizing waste generation by maximizing the potential use of resources.

b Alternative use of waste - this type of handling process goes beyond the recycling process to the use of upcycling (recycling with the addition of value).

From a scientific perspective, especially for Indonesian academics, more research studies suitable for future indexing on Scopus are highly encouraged. Those related to the review of papers on waste management, as well as original research about the pyrolysis of solid wastes (medical, plastic, etc.) will be important to close the research and publication gaps for waste management in Indonesia during the COVID-19 pandemic era. 


\section{Conclusions}

In this paper, a systematic literature review and bibliometric analysis for the Scopusindexed publications for the topic of waste handling or waste management in Indonesia during the COVID-19 pandemic era were performed. From 230,000 entries in Scopus, this systematic literature review successfully identified and extracted 24 core publications with keywords related to "covid", "indonesia", "waste", and the affiliated country of Indonesia. Moreover, the review of the 24 core publications was summarized and discussed in this paper. The review was further reinforced by a bibliometric analysis that unraveled the current condition regarding the topic of waste handling and waste management in Indonesia during the COVID-19 pandemic era, where there are four main clusters of potential development for waste handling or waste management in Indonesia during the COVID-19 pandemic era, namely (1) medical wastes and their treatments, (2) COVID-19, (3) Indonesia and waste management, and (4) solid waste. Furthermore, bibliometric analysis also unveiled the research and publication gap for the topics of review, pyrolysis, catalytic pyrolysis, environmental impact, medical waste management, and health care. This paper as a systematic literature review and bibliometric analysis is an attempt to close this particular gap for the future study of waste management in Indonesia both during and after the COVID-19 pandemic.

Author Contributions: Conceptualization, D.M. and A.A.; methodology, D.M. and A.A.; software, D.M.; writing—original draft preparation, H.F. and D.J.C.H.; writing—review and editing, D.M.; visualization, H.F. and D.J.C.H.; supervision, D.M.; project administration, A.A. All authors have read and agreed to the published version of the manuscript.

Funding: This research received no external funding.

Institutional Review Board Statement: Not applicable.

Informed Consent Statement: Not applicable.

Data Availability Statement: Not applicable.

Acknowledgments: The authors would like to thank Shierly Chandra, Claresta Constantine, Valerie A. Bowie, and Airelia Pranita for their kind support for this study.

Conflicts of Interest: The authors declare no conflict of interest.

\section{Nomenclature}

\begin{tabular}{|c|c|}
\hline AHP & analytic hierarchy process \\
\hline CCTV & closed-circuit television \\
\hline COVID-19 & coronavirus disease 2019 \\
\hline DKI & Daerah Khusus Ibukota (special region for the national capital) \\
\hline DOC & dissolved organic carbon \\
\hline IoT & internet of things \\
\hline LCA & life cycle analysis \\
\hline PPE & personal protective equipment \\
\hline PRISMA & preferred reporting items for systematic reviews and meta-analyse \\
\hline SNI & standar nasional Indonesia (Indonesian National Standard) \\
\hline TPI & twist per inch \\
\hline
\end{tabular}

\section{References}

1. Worldometer. COVID-19 Coronavirus Pandemic 2021. Available online: https://www.worldometers.info/coronavirus/ (accessed on 31 December 2021).

2. Tassakka, M.I.S.; Musrianton, M.; Alsita, I.; Runtu, K.G.A.; Normayasari; Ndahawali, D.H. Modeling the impact of the COVID-19 pandemic on air emissions indicators of climate change originating from solid waste management in coastal settlements. IOP Conf. Ser. Earth Environ. Sci. 2020, 584, 012062. [CrossRef]

3. Mahendradhata, Y.; Andayani, N.L.P.E.; Hasri, E.T.; Arifi, M.D.; Siahaan, R.G.M.; Solikha, D.A.; Ali, P.B. The Capacity of the Indonesian Healthcare System to Respond to COVID-19. Front. Public Health 2021, 9, 649819. [CrossRef] [PubMed] 
4. Cordova, M.R.; Nurhati, I.S.; Riani, E.; Nurhasanah; Iswari, M.Y. Unprecedented plastic-made personal protective equipment (PPE) debris in river outlets into Jakarta Bay during COVID-19 pandemic. Chemosphere 2021, 268, 129360. [CrossRef] [PubMed]

5. Warmadewanthi, I.D.A.A.; Wulandari, D.; Cahyadi, M.N.; Pandebesie, E.S.; Anityasari, M.; Dwipayanti, N.M.U.; Purnama, I.G.H.; Nisaa, A.F. Socio-economic impacts of the COVID-19 pandemic on waste bank closed-loop system in Surabaya, Indonesia. Waste Manag. Res. 2021, 39, 1039-1047. [CrossRef] [PubMed]

6. Muhjad, M.H.; Razy, F.; Hadin, A.F. The problematics of management personal protection equipment waste related to COVID-19 in indonesia. Sriwij. Law Rev. 2021, 5, 300-308. [CrossRef]

7. Mangindaan, D.; Chen, C.-T.; Wang, M.-J. Integrating sol-gel with cold plasmas modified porous polycaprolactone membranes for the drug-release of silver-sulfadiazine and ketoprofen. Appl. Surf. Sci. 2012, 262, 114-119. [CrossRef]

8. Mangindaan, D. Community Services in Indonesia Regarding Waste Handling and Management: Mapping and Bibliometric Analysis. Int. J. Community Serv. 2021, 1, 344-357.

9. Agamuthu, P.; Barasarathi, J. Clinical waste management under COVID-19 scenario in Malaysia. Waste Manag. Res. 2021, 39, 18-26. [CrossRef]

10. Kothari, R.; Sahab, S.; Singh, H.M.; Singh, R.P.; Singh, B.; Pathania, D.; Singh, A.; Yadav, S.; Allen, T.; Singh, S.; et al. COVID-19 and waste management in Indian scenario: Challenges and possible solutions. Environ. Sci. Pollut. Res. 2021, 28, 52702-52723. [CrossRef]

11. Shammi, M.; Rahman, M.M.; Ali, M.L.; Khan, A.S.M.; Siddique, M.A.B.; Ashadudzaman, M.; Bodrud-Doza, M.; Alam, G.M.M.; Tareq, S.M. Application of short and rapid strategic environmental assessment (SEA) for biomedical waste management in Bangladesh. Case Stud. Chem. Environ. Eng. 2022, 5, 100177. [CrossRef]

12. Baas, J.; Schotten, M.; Plume, A.; Côté, G.; Karimi, R. Scopus as a curated, high-quality bibliometric data source for academic research in quantitative science studies. Quant. Sci. Stud. 2020, 1, 377-386. [CrossRef]

13. Muhammad, J.; Risanto, J.; Gimin. Temperature characteristics of post-harvest technology equipment based on biomass waste energy using the internet of things telecontrol system. J. Phys. Conf. Ser. 2021, 2049, 012023. [CrossRef]

14. Dharmaraj, S.; Ashokkumar, V.; Pandiyan, R.; Halimatul Munawaroh, H.S.; Chew, K.W.; Chen, W.H.; Ngamcharussrivichai, C. Pyrolysis: An effective technique for degradation of COVID-19 medical wastes. Chemosphere 2021, 275, 130092. [CrossRef]

15. Purnomo, C.W.; Kurniawan, W.; Aziz, M. Technological review on thermochemical conversion of COVID-19-related medical wastes. Resour. Conserv. Recycl. 2021, 167, 105429. [CrossRef] [PubMed]

16. Suryawan, I.W.K.; Sarwono, A.; Septiariva, I.Y.; Lee, C.H. Evaluating marine debris trends and the potential of incineration in the context of the COVID-19 pandemic in Southern Bali, Indonesia. J. Ilm. Perikan. Dan Kelaut. 2021, 13, 70-78. [CrossRef]

17. Hartanto, B.W.; Mayasari, D.S. Environmentally friendly non-medical mask: An attempt to reduce the environmental impact from used masks during COVID 19 pandemic. Sci. Total Environ. 2021, 760, 144143. [CrossRef]

18. Joes, S.; De Candra, C.; Larsen, H.; Marchello, D.; Daywin, F.J.; Gozali, L.; Widodo, L.; Adianto, A.; Salomon, L.L.; Irawan, A.P. The design development of an ergonomic public trash bin for COVID-19 medical mask waste. In Proceedings of the International Conference on Industrial Engineering and Operations Management, Singapore, 7-9 March 2021; pp. 2756-2769.

19. Rachmawati, R.; Mei, E.T.W.; Nurani, I.W.; Ghiffari, R.A.; Rohmah, A.A.; Sejati, M.A. Innovation in coping with the COVID-19 pandemic: The best practices from five smart cities in Indonesia. Sustainability 2021, 13, 12072. [CrossRef]

20. Latif, F.; Chadijah, S.; Fanthi, R. Implementation of Reusable Plastic Waste and Electronic Cable Waste as Space Divider: Responding Sustainability Issue in New Normal Living-Study Case in a Small Coffee Shop. IOP Conf. Ser. Earth Environ. Sci. 2021, 794, 012154. [CrossRef]

21. Sani, S.; Warly, L.; Zudri, F.; Novia, R.; Fadri, R.A. Chlorella vulgaris supplementation as mineral source of zinc and selenium to improve the quality of goat milk as health drink in COVID-19 pandemy. IOP Conf. Ser. Earth Environ. Sci. 2021, 757, 012051. [CrossRef]

22. Prajitno, J.H.; Sulistiawati, F.K.; Caessario, J.; Sofyan, N.; Ari, B.; Putri, A.A.; Nureta, A.; Rafikasari, A.; Christi, L.; Farouq, H. The proper use of face mask during COVID-19 pandemic in urban community. Gac. Med. Caracas 2021, 129, S299-S304.

23. De Leon, M.V.; Susilo, D.; Putranto, T.D.; Hartati, F.K.; Santos, R.R.T. Managing the uncertainty during COVID-19 pandemic: Communicating disaster and food industry sustainability. IOP Conf. Ser. Earth Environ. Sci. 2021, 819, 012039. [CrossRef]

24. Hantoko, D.; Li, X.; Pariatamby, A.; Yoshikawa, K.; Horttanainen, M.; Yan, M. Challenges and practices on waste management and disposal during COVID-19 pandemic. J. Environ. Manag. 2021, 286, 112140. [CrossRef] [PubMed]

25. Rozana, K.; Susanti, E.; Saputra, I.K.; Ciptawati, E.; Kurniawan, D.T. Microbiome analysis of medical mask waste as an early step to prevent environmental pollution due to unstandardized waste treatment strategies. IOP Conf. Ser. Earth Environ. Sci. 2021, 802, 012036. [CrossRef]

26. Rozana, K. Orf 1 as a gene marker for fast screening in medical waste treatment applications during a COVID-19 pandemic. IOP Conf. Ser. Earth Environ. Sci. 2021, 802, 012037. [CrossRef]

27. Rahayu, P.; Rohajawati, S.; Fairus, S.; Saragih, H.; Akbar, H. Challenges and Recommendation of the Information Technologies Application in Hazardous Medical Waste Management amidst Pandemic COVID-19. J. Phys. Conf. Ser. 2021, 1844, 012029. [CrossRef]

28. Febrianto, G.; Karisma, D.; Mangindaan, D. Polyetherimide nanofiltration membranes modified by interfacial polymerization for treatment of textile dyes wastewater. IOP Conf. Ser. Mater. Sci. Eng. 2019, 622, 012019. [CrossRef] 
29. Karisma, D.; Febrianto, G.; Mangindaan, D. Polyetherimide thin film composite (PEI-TFC) membranes for nanofiltration treatment of dyes wastewater. IOP Conf. Ser. Earth Environ. Sci. 2018, 195, 012057. [CrossRef]

30. Dhama, K.; Patel, S.K.; Yatoo, M.I.; Tiwari, R.; Sharun, K.; Dhama, J.; Natesan, S.; Malik, Y.S.; Singh, K.P.; Harapan, H. SARS-CoV-2 existence in sewage and wastewater: A global public health concern? J. Environ. Manag. 2021, 280, 111825. [CrossRef]

31. Takeda, T.; Kitajima, M.; Huong, N.T.T.; Setiyawan, A.S.; Setiadi, T.; Hung, D.T.; Haramoto, E. Institutionalising wastewater surveillance systems to minimise the impact of COVID-19: Cases of Indonesia, Japan and Viet Nam. Water Sci. Technol. 2021, 83, 251-256. [CrossRef]

32. Suryawan, I.W.K.; Rahman, A.; Septiariva, I.Y.; Suhardono, S.; Wijaya, I.M.W. Life Cycle Assessment of solid waste generation during and before pandemic of COVID-19 in Bali province. J. Sustain. Sci. Manag. 2021, 16, 11-21. [CrossRef]

33. Zaid, S.; Aziz, M.A.; Sulaiman, R.; Simarani, K.; Suyoto, Y.T.; Lou, E.; Esfandiari, M. Review of coronavirus transmission in urban clusters: Survival in water and wastewater systems. J. Des. Built Environ. 2020, 20, 85-102. [CrossRef] 